\title{
THE ASSOCIATION BETWEEN AGE, BODY MASS INDEX, HORMONAL CONTRACEPTIVE, AND NON COMMUNICABLE DISEASE: A STUDY USING THE INDONESIAN FAMILY LIVE SURVEY-5
}

\author{
Danies Tunjung Pratiwi'), Vitri Widyaningsih²) \\ ${ }^{1)}$ Masters Program in Public Health, Universitas Sebelas Maret \\ ${ }^{2)}$ Faculty of Medicine, Universitas Sebelas Maret
}

\begin{abstract}
Background: Non-communicable diseases (NCDs) are the main sources of disease burden. Obesity is a challenging epidemic and increased body mass index (BMI) influences on almost all body systems leading to development of non-communicable diseases. The purpose of this study was to examine the association between age, body mass index, hormonal contraceptive, and NCD.

Subjects and Method: This was a cross sectional study carried out in 13 provinces in Indonesia. A sample of 10,233 women of reproductive age was selected for this study. The dependent variable was non-communicable disease (NCD) for hypertension and cholesterol. The independent variables were hormonal contraceptive, overweight, and age. The data were obtained from Indonesian Family Live Survey 5 (IFLS). The data were analyzed by a multiple logistic regression.

Results: Hormonal contraceptive users were 79.2\%. Prevalence of hypertension and cholesterol was $13.6 \%$. The risk of NCD increased with overweight (aOR $=1.90 ; 95 \%$ $\mathrm{CI}=1.67$ to $2.16 ; \mathrm{p}<0.001)$ and age $(\mathrm{aOR}=1.08 ; 95 \% \mathrm{CI}=1.07$ to $1.09 ; \mathrm{p}<0.001)$. Hormonal contraceptive was positively associated with NCD but it was statistically non-significant $(\mathrm{aOR}=1.09 ; 95 \% \mathrm{CI}=0.93$ to $1.29 ; \mathrm{p}=0.285)$.

Conclusion: The risk of NCD increases with overweight and age. Hormonal contraceptive is positively associated with NCD but it is statistically non-significant.

Keywords: hormonal contraception, non-communicable disease, hypertension, cholesterol, age

\section{Corespondence:}

Danies Tunjung Pratiwi. Masters Program in Public Health, Universitas Sebelas Maret, Jl. Ir. Sutami 36 A, Surakarta 57126, Central Java, Indonesia. Email: daniestunjung@gmail.com. Mobile: +6285229209108.
\end{abstract}

The $5^{\text {th }}$ International Conference on Public Health Best Western Premier Hotel, Solo, Indonesia, February 13-14, 2019 | 87 https://doi.org/10.26911/theicph.2019.01.23 